Acta Crystallographica Section A

Foundations of Crystallography

ISSN 0108-7673

\section{A tribute to W. L. Bragg by his younger daughter}

\author{
Patience Thomson
}

Queens Croft, 16a Castle Street, Wallingford, Oxon, OX10 8DW, United Kingdom. Correspondence e-mail: Patience.Thomson@btinternet.com
How can I condense my father's vibrant personality, his multifaceted skills and boundless enthusiasm into less than 2000 words?

And indeed, since WLB is claimed to have been the first Australian to win the Nobel Prize, I also need briefly to explore how strongly Dad was influenced by his Australian background. Did he think of himself as Australian?

I am going to turn that question round and ask whether other people thought of him as Australian. Before the First World War, when my father came to England, society was very stratified. You were classified according to your background. People were very conscious of class, social standing and education. They belonged to very distinct social circles which did not often mix.

When WLB went up to Trinity College, Cambridge, he would have found that the vast majority of students fell into two categories. They had either gone to 'public' schools, (which, just to confuse, are the private ones in England) and were the sons of the gentry and the relatively wealthy, or they were the clever grammar-school boys, often on scholarships. You chose your friends and spent your free time with others of like background, often those who had been to the same school. Dad did not quite fit into either category. He was a 'colonial' and therefore did not have easy reference to a particular group.

Having said this, my father had certain advantages and skills which fostered close friendships. The first lay in his sporting prowess. He was proficient across a wide spectrum of disciplines including tennis, hill walking, sailing, skiing, athletics and horse-riding.

WLB's physical fitness and love of the outdoors always seemed to me to be an integral part of his Australian heritage. He often said how striking it was that the Australian soldiers in the First World War were so much fitter than their British counterparts, although many came of the same stock.

Dad was an excellent horseman. He was enrolled in the cavalry at the start of hostilities, but he was not the man to enjoy regimental formalities and convivial drinking in the Officers' Mess. He was much happier when he was transferred to a job which involved sound-ranging the enemy guns. His two colleagues in this enterprise were Canadian and French, and not from the British establishment at all. They were to become good and loyal friends.

His second advantage was his wide range of intellectual strengths, which won him the respect of the academic community in Cambridge. St Peter's College, Adelaide University and his close proximity to his father and his physics laboratory had laid some firm foundations. Science was not his only interest. He had had an excellent and broad education in Australia which included the classics. Dad was a thoroughly cultured man. As an 'outsider' from the other side of the world, he viewed the English social scene with objectivity and humour. He was a splendid conversationalist and a great teller of jokes. He did not naturally bow to the English social hierarchy.

My father told us many tales of his childhood and teenage years in Australia. He had obviously loved the wide open spaces, riding on the beach, picnicking in the hills, the family excursions. Dad enjoyed cooking on an open fire, building a log cabin or carving a boomerang that really worked. He had inherited a measure of the pioneering spirit from his grandfather, Sir Charles Todd, with whom he spent a lot of time.

Dad was endlessly creative with a very visual imagination. He made shadow plays for us, with a Noah's Ark that really rocked and a dinosaur that roared. He made fantastic train layouts for the boys. He was very good with his hands, making me perfect miniature furniture for the dolls' house. He once told me he would have been a toymaker if he hadn't been a scientist.

Dad brought with him to England some lifelong hobbies from Australia. His interest in natural history was one,

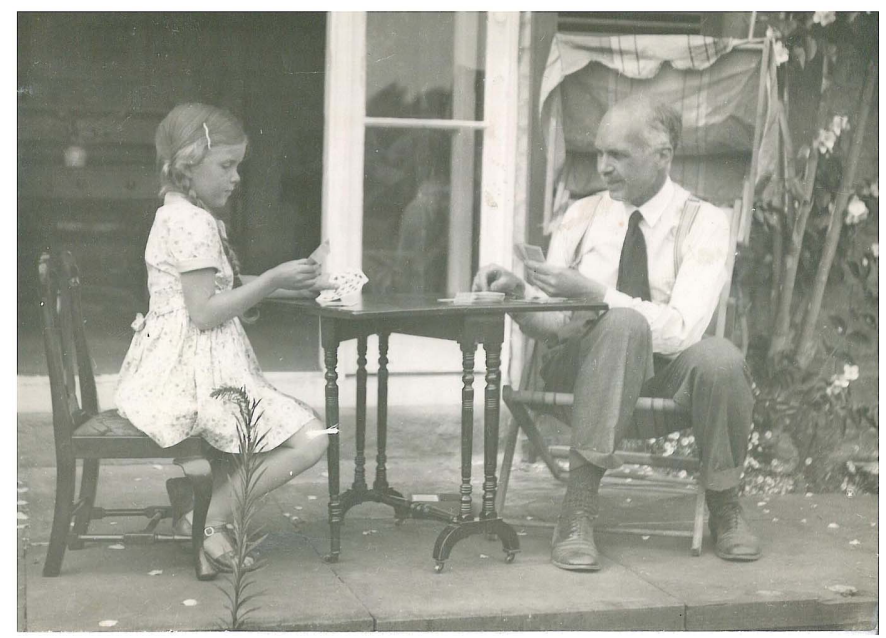

Figure 1

Together with my father in 1943. 


\section{Bragg centennial}

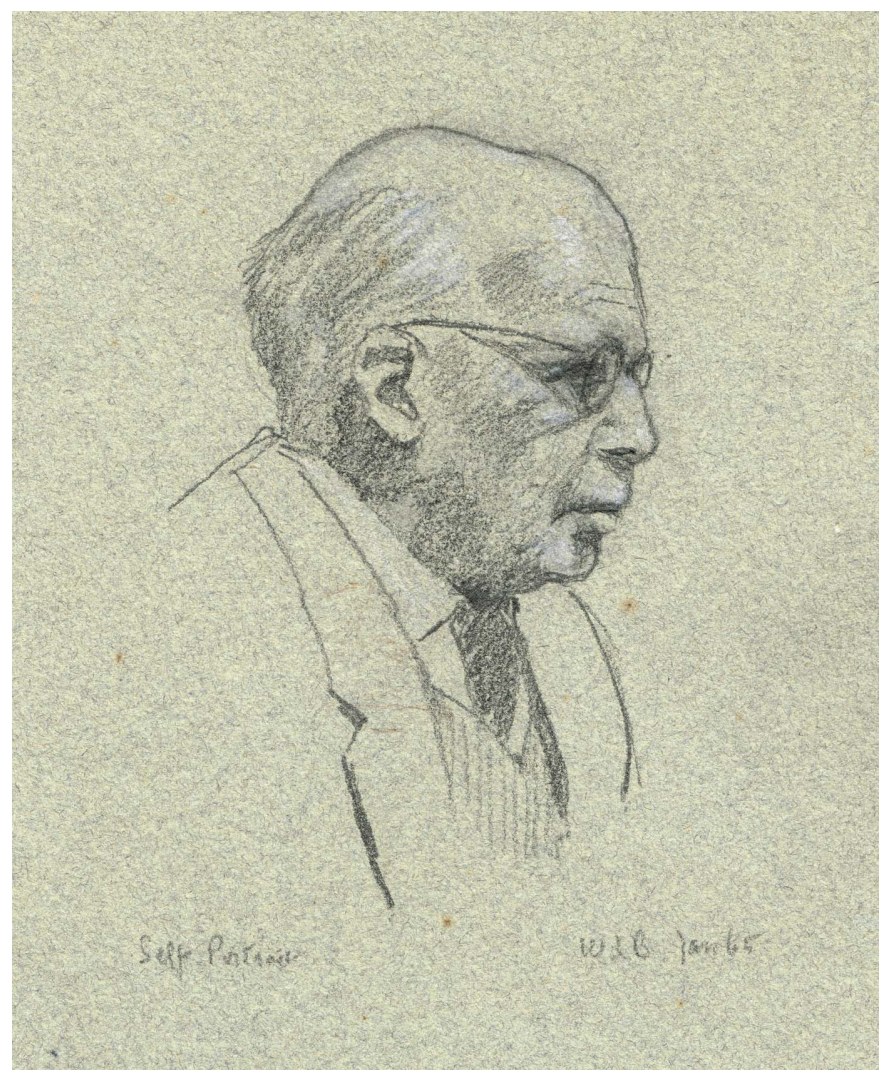

Figure 2

Self portrait by Lawrence Bragg (January 1965).

gardening another and watercolour painting another. In gardening he preferred to have a gorgeous cacophony of colour, reminding him of his native Australia, in contrast to the tasteful paler shades which were favoured in the fashionable English establishment. His painting was of an almost professional standard. His mother, born and bred in Australia, belonged to a South Australian group of artists. She taught him the necessary skills, and sketching became a lifelong passion. His portraits were witty and accurate. His self portrait, achieved with mirrors, is amazingly skilful.

He left behind many of his extensive and close-knit family when he came to England. Even though he did not return to Australia for many years, he still felt part of this family.

After his marriage to my mother, much changed for my father. She enjoyed the social life, had many contacts and introduced my father to a wide range of friends and family. Moreover, his growing reputation as a scientist opened many doors within the establishment. His honours over the years, his television appearances and his public roles brought him recognition. But there was a maverick element, an originality of mind and a tendency towards lateral thinking which I always felt was a legacy of his Australian upbringing. For all these and many other reasons, I believe my father not only felt different from the traditional true Brit who stayed in the UK, but was intensely proud of his Australian heritage.

My father had a great sense of destination, of distance travelled, and relished the joy of seeing any project through to a recognizable and satisfactory conclusion. He often declared how wonderfully lucky he had been to see the whole science of crystallography grow from the analysis of simple structures to the amazing complexity of DNA and the protein molecules. $\mathrm{He}$ was born at the right time; he had the right opportunities and he was very conscious of that fact. He also believed, and it was part of his philosophy of life, that everything had a pattern and a purpose.

I remember when WLB first showed me the model of the structure of lysozyme. He said 'It is such a pleasing solution and so beautiful. It must be right.' I had the model of lysozyme on my lap in the aeroplane when we travelled to Berlin, where he was going to lecture.

As we landed I saw a crowd waiting at the airport. Someone was holding a huge bouquet of flowers. I imagined they were there for a well known pop group who were travelling on our plane. But the crowd was there for my father - and the flowers were for me. My father was a very modest man and he was astonished at this reception. He was also delighted.

My father was one of the most focused people I have ever met. Apart from his work, he filled the unforgiving minute with his hobbies and interests. This was his salvation in that he could relax easily and quickly, immersed in some ploy or activity that fully engaged both his mind and his energy. In summer I would awake to the sound of his well honed scythe in the long grass outside my window. Then a hearty breakfast and ten minutes to complete the Times crossword. (Now he himself has reached a status where the name Bragg has twice recently been the answer to a clue.) Then he was off on his bicycle to give a 9 o'clock lecture.

Dad loved detective stories and would happily immerse himself in one when he wanted to take a breather. I think he liked the genre because all of the loose ends were tied up in the last chapter. He was mortified to learn after sitting next to a certain Lady Mallowan at dinner one night that she was in fact Agatha Christie. Once he insisted that the man in the pew in front remove his homburg hat in church on Christmas Eve, only to discover that the 'man' was Dorothy Sayers.

When the snow lay deep in 1947, he built an Eskimo igloo and a ski jump.

My father was endlessly knowledgeable and a great teacher. On walks he could identify the birds, butterflies, flowers and even the insects - 'By Jove,' he exclaimed in Corfu, to my astonishment, 'there's a praying mantis.' From an early age he identified and explained to us the patterns in nature, in astronomy and meteorology.

My father enjoyed his food. When we were together (my mother had a distinguished career of her own and was often away) we lived on chocolate semolina pudding and only did the washing up the day before she got back.

In restaurants my parents caused me great embarrassment as a child. 'Look over there dear,' my mother would whisper in my father's ear. 'There's a woman wearing the most extraordinary purple hat.' Dad would half raise himself from his seat, look around and boom out 'Lady with a mad purple hat where?' He loved to re-enact this story and laughed uproariously at his own jokes. 
Music was a complete blank in my father's life. Both he and my father-in-law Sir George Thomson only knew that God Save the Queen was being played because everyone else stood up. A visit to the opera was punishment indeed. They recognized no pattern or purpose in music - however, there was one exception. Both enjoyed the familiar old-fashioned hymns of their childhood.

Indeed, my father was what he termed a 'blue sky' worshipper, which meant, in his terms, that he gardened when we were taken to church on Sunday. When I challenged him as a teenager on his religious beliefs, he replied that the evidence of God was in the visual world and that whatever the arrangements for the afterlife turned out to be, he was convinced that they would be satisfactory. He could not be drawn any further.

Dad spoke French and German badly, and had read the classics (though most of French literature he happily dismissed as tripe). He read Latin and Greek fluently and re-read the Odyssey every ten years in the original. He could talk about philosophy but not politics, and about the impressionists but not 'modern' art, most of which he considered pointless.

'Be careful what you set your heart on, for you will surely get it,' he used to say to me. This meant that you mustn't spend your life climbing a mountain, only to discover at the top that it is the wrong one. Think it out, work out your best plan, don't plunge in and hope for the best.
When I got married, WLB had two pieces of good advice. 'Never feel sorry for yourself, it kills all sympathy in your partner' and 'never put your husband in the doghouse for too long.'

It was partly my mother's influence that I learnt so little of science. She could never remember the order of the letters in DNA (NAD, AND). She was intelligent, motivated and fun; Mayor of Cambridge, magistrate, and Chairman of Marriage Guidance, as it was then called. Her vivacity and charm, and her love of people and parties and the social world was in complete contrast to my father's more serious attitude to life, and yet they were a devoted couple, complementary in so many ways. She taught my father how to have fun.

How did my father get round to so much and still have time to pursue his scientific work? Well, he avoided 'time wasting' on administration and committees. He refused to become Master of both an Oxford and a Cambridge college when the jobs were offered. He knew his own limitations and possessed a healthy streak of ruthlessness. Life was too short to spend on activities that were uncongenial.

If my father felt himself to be very lucky to have been born in the right place at the right time, I have always considered myself very lucky to have been his daughter. He inspired me with the possibility of creating pattern and purpose in my own life, but left me to decide what direction I would take. He created air under my wings and encouraged me to fly. Thank you, Dad. 